\title{
Medicare and the U.S. Unfunded Liability
}

\author{
Gilbert Berdine MD
}

The recent U.S. government shutdown has brought disagreements over U.S. government fiscal policy to public attention. These discussions focus most often on the short term imbalances between government revenues and expenditures known as the budget deficit. As the deficit has increased both in nominal terms and as a fraction of GDP, more people are looking at the sustainability of the situation or the longer term picture. Given that retirement programs, such as Social Security and Medicare, are becoming larger determinants of both the short term and long term imbalances, increasing attention is being drawn to the actuarial concepts of unfunded liabilities. The long term imbalances are derived from projections of the short term imbalances over time using actuarial methods. This article will explain the concept of unfunded liability and analyze the contribution of Medicare to this long term problem.

The U.S. budget deficit is a number reflecting the short term imbalances between government revenues and expenditures over a one year time period. For the most recently concluded fiscal year (2013), the official estimate of total U.S. government revenue was $\$ 2.9$ trillion, the official estimate of total U.S. government expenditure was $\$ 3.8$ trillion, and the official U.S. budget deficit was $\$ 0.9$ trillion. ${ }^{1}$ Of the $\$ 3.8$ trillion in expenditures, $\$ 2.563$ trillion $(67.4 \%)$ was for Human Resources. Of the total Human Resources budget, $\$ 825$ billion was for Social Security, $\$ 559$ billion was for Welfare, $\$ 530$ billion was for Medicare, and $\$ 386$ billion was for Health (mostly Medicaid). The $\$ 0.9$ trillion deficit is financed by a combination of borrowing and the creation of fiat money through the Federal Reserve. Historically, the U.S. government

Corresponding author: Gilbert Berdine MD Contact Information: Gilbert.Berdine@ttuhsc.edu DOI: 10.12746/swrccc 2014.0205.055 financed its deficits through borrowing, but since the collapse of Lehman Brothers and the TARP bailout, the Federal Reserve has purchased a large percentage of new U.S. Treasury debt offerings by creating money as central bank reserves.

The recent news about raising the debt limit, the government shutdown, the budget sequester, and continuing resolutions are all about the short term fiscal deficit. Creeping into the discussion has been longer term imbalances called unfunded liabilities. The budget deficit reflects cash basis accounting. A corporation with a pension plan is required by law to use accrual basis accounting to ensure that in future years the pension promises made today will be kept. Accrual basis accounting looks at longer time frames and balances projections of present and future expenses with the projections of present and future incomes. A projected fiscal gap or unfunded liability must be corrected in the present with changes in revenue policy, expense policy, or a combination of the two. Obviously, the utility of accrual basis accounting depends on the accuracy of its projections. David Walker, the U.S. Comptroller General from 1998-2008, and Laurence Kotlikoff, an economics professor at Boston University, have been calling attention to the unsustainable fiscal path of the U.S. largely due to promises made to future Americans via Medicare.

Professor Kotlikoff has the most pessimistic figures. His estimate of the unfunded liability or long term fiscal gap is $\$ 222$ trillion as of December, 2012 . $^{2}$ Critics of accrual basis accounting point out those future liabilities can be adjusted by a future Congress to meet the needs of the future situation. The problem with kicking the can down the road is that the required corrective actions increase over time. Prof. Kotlikoff estimates that the fiscal gap increased by $\$ 11$ trillion in 2012. Correction of the problem would require an immediate and permanent $36 \%$ cut in all non-interest federal spending or an immediate and permanent 
increase in federal taxes by $55 \%{ }^{3}$ Neither of these changes is politically feasible.

Other estimates of the unfunded liability are more sanguine. The U.S. Debt Clock indicates a total U.S. unfunded liability of $\$ 126$ trillion of which Medicare accounts for $\$ 87.6$ trillion. ${ }^{4}$ The organization cites the Federal Reserve as the source of its figures. When U.S. Senator Tom Coburn cited these figures, the Washington Post "Fact Checker" criticized the senator and gave him 3 Pinocchios. ${ }^{5}$ The Post cited a report by the National Center for Policy Analysis which estimated the total U.S. unfunded liability at $\$ 84$ trillion of which $\$ 30$ trillion represents money promised to current retirees. ${ }^{6}$ The Post's conclusion was, "Still, $\$ 30$ trillion, while large, is not nearly as large as $\$ 128$ trillion." This optimism assumes that all future retirees will receive no benefits even as they continue to pay for current retirees, a policy change that does not seem terribly likely to happen.

Any projection of the unfunded liability must make assumptions about changes in the number of beneficiaries, changes in per person benefit, changes in the number of taxpayers, changes in wages, and changes in tax rates. There is plenty of room for different assumptions leading to different projections.

\section{Figure I.1 Medicare Expenditures as a Percentage of the Gross Domestic Product under Current Law and Illustrative Alternative Projections}

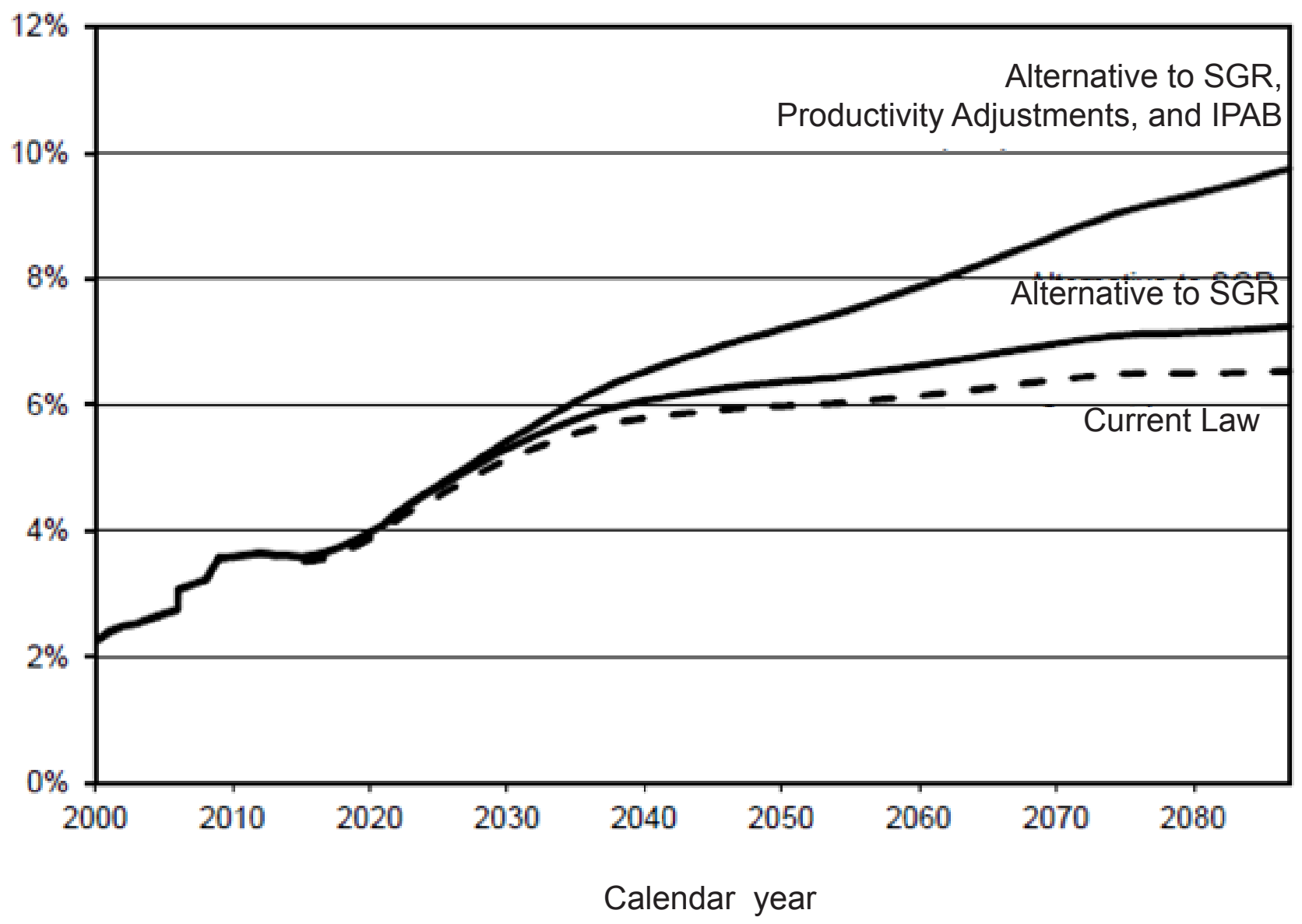


The Medicare Trustees project different levels of expenditures depending on whether Congress continues to rescind legislated payment reductions to hospitals and physicians. ${ }^{7}$ Different assumptions necessarily lead to different results. These different assumptions are not mere technicalities. The "high cost" methodology assumes that promises will be kept regardless of the resources required to keep them. The "low cost" methodology assumes that resource limitations will assert themselves as broken promises which are a form of default.

The "low cost" curve is labeled "current law" which, though technically correct, is misleading. As part of a past budget "compromise" Congress created increased benefits in the present to be paid for by reduced payments in the future. Congress has rescinded the mandated cuts in payments to hospitals and doctors every year and will likely continue to do so. The likelihood is high enough that the Medicare Trustees include projections based on that "high cost" assumption. The Washington Post's "low" estimate of the unfunded liability is based on the Medicare Trustees "low cost" projection that nobody believes is very likely. Even this "low" figure of \$84 trillion still represents over five years of GDP which should have been saved but was spent instead.

The long term problem of unfunded liabilities cannot be solved without first solving our short term problem of perennial budget deficits. Medicare is a big part of the current short term problem. At first glance, the current deficit in Medicare ( $\$ 37.3$ billion $)^{7}$ appears to be a small problem. This deficit is a gap between Medicare income of $\$ 536.9$ billion and expenditures of $\$ 574.2$ billion. $^{7}$ The deficit problem is much larger than it first appears, however, as \$214 billion from "general revenue" is counted as income. ${ }^{7}$ While the Part A or hospital insurance portion of Medicare is funded largely from Medicare taxes, Parts B and $D$ are funded largely by the same general revenue that is in perennial deficit. Neither the short term problems of the U.S. budget deficit nor the long term problems of unfunded liabilities can be solved without significant structural changes to Medicare.
The "future" problem of unfunded liabilities may be catching up with us sooner than we think. While a great deal of attention was given to raising the debt limit, there was very little discussion about whether foreigners would continue to lend us more money. In 2011 , the Federal Reserve purchased $61 \%$ of new U.S. Treasury issues. ${ }^{8}$ In 2012, this figure increased to $90 \% .^{9}$ China and Japan, the two largest foreign holders of U.S. debt, have become net sellers. ${ }^{10}$ Our debts are being monetized by the Federal Reserve which will eventually lead to price inflation.

Author Affiliation: Dr. Berdine is a pulmonary physician in the Department of Internal Medicine, TTUHSC.

Received: $10 / 28 / 2013$

Accepted: $12 / 4 / 2013$

Reviewers: Mark Funderburk, MBA; Brent D Magers, FACHE Published electronically: 1/16/2014

\section{References}

1. http://www.whitehouse.gov/sites/default/files/omb/budget/fy2013/assets/hist.pdf

2. http://www.realclearpolicy.com/blog/2012/12/01/economist_laurence_kotlikoff_us_222_trillion_in_debt_363. html

3. http://www.zerohedge.com/news/2013-09-11/lawrencekotlikoff-us-fiscal-gap-200-trillion-our-country-broke 4. http://www.usdebtclock.org/

5. http://www.washingtonpost.com/blogs/fact-checker/ $\mathrm{wp} / 2013 / 10 / 23 /$ does-the-united-states-have-128-trillionin-unfunded-liabilities/

6. http://www.ncpa.org/pdfs/st338.pdf

7. http://www.cms.gov/Research-Statistics-Data-and-Systems/Statistics-Trends-and-Reports/ReportsTrustFunds/ Downloads/TR2013.pdf

8. http://online.wsj.com/news/articles/SB1000142405270 2304450004577279754275393064

9. http://www.bloomberg.com/news/2012-12-03/treasuryscarcity-to-grow-as-fed-buys-90-of-new-bonds.html 10. http://www.reuters.com/article/2013/08/16/ us-usa-economy-capital-idUSBRE97F02T20130816 